\title{
Design E-Ticketing System to Increase Ticket Sales in Banyuwangi Branch New Star Cineplex
}

\author{
Anak Agung Gde Satia Utama ${ }^{1, *}$, Pending Puji Dwi Astuti², Eka Elmi \\ Hikmawati $^{3}$, Yashinta Setyowati ${ }^{4}$ \\ ${ }^{1}$ Accounting Department, Economics and Business Faculty, Universitas Airlangga, Surabaya, Indonesia \\ ${ }^{2}$ Accounting Department, Economics and Business Faculty, Universitas Airlangga, Surabaya, Indonesia \\ ${ }^{3}$ Accounting Department, Economics and Business Faculty, Universitas Airlangga, Surabaya, Indonesia \\ ${ }^{4}$ Accounting Department, Economics and Business Faculty, Universitas Airlangga, Surabaya, Indonesia \\ *Corresponding author. Email: gde.agung@feb.unair.ac.id
}

\begin{abstract}
In the modern era, technology has developed very fast. Trades that are carried out manually have been able to switch to electronic media (e-commerce). E-commerce can also be applied in ordering or purchasing tickets online (e-ticketing). E-ticketing is already running on companies engaged in transportation, such as airlines and trains. However, e-ticketing also has potential if it is applied to booking or selling tickets at the cinema. In Banyuwangi, there is one cinema, namely New Star Cineplex (NSC). Seeing the economic growth and per capita income of the people of Banyuwangi, which continues to increase. From 2010 to 2014 it was $70 \%$ from IDR 14.97 million in 2010 to IDR 25.5 million in 2014 (www.banyuwangikab.go.id). Furthermore, according to the law of supply and demand, the demand for modern entertainment in cinema is also increasing. The current system at NSC is that ticket purchases can only be made on the spot.

Spectators must arrive early and can only purchase tickets at NSC. For people who are quite busy, it is not efficient. The problem is that the audience is forced to go home because the tickets to be purchased have run out and come back at the next screening or look for other entertainment alternatives. The impact is to reduce the number of ticket sales in 2015, 79,743 tickets and decreased in 2016 to 57,610 tickets. So, this research focuses on the system development design that the NSC Banyuwangi branch has implemented into an e-ticketing system. The type of research used is exploratory qualitative research carried out at the Banyuwangi branch of NSC. Data were analyzed using descriptive exploratory and content analysis methods. The primary and secondary data used are processed and analyzed using journals and books related to e-commerce, development, and information systems. The expected result of this research is the design of an e-ticketing system to increase ticket sales at the Banyuwangi branch of NSC.
\end{abstract}

Keywords: System Design, E-commerce, E-Ticketing, Sales, tickets, NSC, Banyuwangi.

\section{INTRODUCTION}

Technology has developed very quickly. Many companies use e-commerce, especially in the transportation sector, such as airlines and trains. The use of systems e-commerce makes it easier for customers to purchase tickets. So, the development of system e-commerce is needed to optimize the benefits of e-commerce both from the customer and producer sides.
One of the businesses that also requires the development of system e-commerce is modern entertainment, one of which is cinema. Seeing the economic growth and per capita income of the Banyuwangi community continues to increase. From 2010 to 2014 , it was $70 \%$ from IDR 14.97 million in 2010 to IDR 25.5 million in 2014 [1], by the law of supply and demand, so the demand for modern entertainment in the form of cinemas is also increasing. According to Rosyid, an employee of the Banyuwangi branch of NSC, the problem that occurred in the audience was that the audience had to go home because the tickets to be purchased had run 
out and returned to the screening at the next hour. The NSC also regrets this when customers who cannot buy tickets look for other entertainment as an alternative. Indirectly, this decreased ticket sales from 2015, which amounted to 79,743 tickets to 57,610 tickets in 2016. The system running at NSC currently is that ticket purchases can only be made on the spot. Spectators must arrive early and can only purchase tickets at NSC. For people who have busy work activities, this is quite time-consuming.

The NSC needs a system that can support ticket sales and not disappoint the audience to overcome this. This study offers the required system design in the form of e-ticketing. The design of the system eticketing will make it easy for customers to access online ticket purchases and see available cinema seats so that audiences can choose the desired place. The NSC employee will be the admin who inputs data into the system and processes it so that the ticket is already available when the customer arrives.

Previous research that became the reference for this research is research from [2], which states that ecommerce can increase the number of customers and sales of company products in Europe, which in the long run will increase economic growth. Whereas in China, it has been proven that tourism promotion media and travel agent bookings become more potential when using e-commerce [3]. This is supported by research conducted by Chian Tan that ecommerce will also reduce the possibility of fraud [4].

The problem in this study is "How is the design of the system e-ticketing to increase ticket sales at New Star Cineplex (NSC) Banyuwangi?" This research aims to design e-ticketing to increase ticket sales at New Star Cineplex (NSC) Banyuwangi. The contribution of this research for researchers, entrepreneurs, and academia are as follows: Improving the ability of researchers in developing Science and Technology in designing systems e-commerce in the form of e-ticketing at New Star Cineplex (NSC) Banyuwangi, Improving efficiency and effectiveness in operational activities, as well as being able to increase ticket sales at NSC Banyuwangi, and develop research on the design of systems e-commerce that is tested and in the long term will be able to be applied by entrepreneurs.

The expected outcomes in this study are: design of system e-ticketing to increase ticket sales at New Star Cineplex (NSC) Banyuwangi, and in the long term, it is hoped that the system design e-ticketing can be implemented in New Star Cineplex (NSC) Banyuwangi

\section{LITERATURE REVIEW}

E-commerce or electronic commerce is a part of the electronic business that buys and sells goods and services through internet media. These transactions include advertising, marketing, customer support, security, delivery, and payments [5].

According to [6], E-commerce is becoming a significant element in an increasingly modern global economic environment. E-commerce can be defined as computer networks, especially the internet, which is used by users to sell or buy products, both goods and services, and share information and communication media. E-commerce can increase efficiency, and the costs incurred by the company will be lower.

The definition of E-commerce has 3 (three) aspects as follows [6] :

1) Aspects of Technology. E-commerce is the application of techniques used to increase business transactions that utilize internet-based websites.

2) Business Aspect. E-commerce is used to provide the ability to buy or sell a product, both in goods and services and supporting information in the form of an internet-based website.

3) Value Aspect. E-commerce is a tool used by a business, both from the customer and consumer side, to create value in internet-based transactions. The goal is to increase efficiency and cut costs when businesses want to improve product quality.

A system can be defined as a network which is a procedure that is interconnected, gathered together to perform an activity or to carry out an activity or complete a particular goal. Information results from data processing into something more beneficial for the recipient, illustrating an event used in decision-making [7].

An information system is a set of interrelated components to collect, process, store, and distribute information used for decision-making and control carried out by the organization [5]. Information systems have three primary activities, namely:

1) Input. This activity relates to the collection of raw data sourced from within the organization and the external environment.

2) Process. This activity is related to processing or converting the raw data that has been obtained into a more meaningful form.

3) Outputs. This activity is related to transferring process information to the user or to the activity to be used. 
The output of a system is information so that quality information has the following characteristics: relevant, reliable, complete, timely, understandable, and verifiable [8].

Development is a clear and structured activity that produces company information system solutions to solve or exploit opportunities. These activities are: System Analysis is the analysis of a problem solved by the company using information systems [5].

1) System Design is the whole of the plan or system model. In addition, the system designer will detail the specifications that will convey the functions that will be identified during the system analysis.

2) During this stage, the system specifications prepared during the design stage are translated into program code.

3) The test was conducted to determine whether the resulting system gives correct results. Testing of an information system can be divided into three types, namely (1) unit test, (2) system test, and (3) acceptance test.

4) Conversion is the process of converting the old system into a new system. Four main conversion strategies can be implemented, namely (1) parallel strategy, (2) direct move strategy, (3) pilot study strategy, and (4) stepwise approach strategy.

\section{5) Production and Maintenance}

Production is a state after the new system is installed and the conversion is complete. Maintenance is a change to the hardware, software, documentation, or procedures in a production system to correct errors, meet new requirements, or improve processing efficiency.

E-Ticketing or electronic ticketing is one way to document the sales process without issuing valuable documents physical or paper tickets. E-Ticketing is generally known as booking a place like a seat on an airplane by confirming it electronically [9]. Once confirmed electronically, ticket bookings can be printed. That way, E-Ticketing does not only use digital tickets. E-Ticketing refers to using a purchase and verification system using an electronic card; ETicketing may involve a top-up service for balances ETicketing. With services E-Ticketing, companies can minimize costs and optimize comfort with ease of service. In this study, the term E-Ticketing refers to ordering seats or seats in a cinema electronically (via a site) and the confirmation process that is carried out electronically to increase easy access to ticket observation.
Technology Acceptance Model (TAM) is the theory most often used to test information systems and technology, especially to explain the individual acceptance of the system. TAM is a development of the Theory of Reasoned Action (TRA), and Davis first introduced TAM in 1989. According to Davis (1989) in [10], states that two factors significantly influence the use of a system. These factors are perceived usefulness, to improve user performance and perceived ease of use, to make it easier for users to learn the system. So this theory is also needed to support the behavior of users e-commerce.

\section{RESEARCH METHOD}

This study used an exploratory qualitative type carried out in Banyuwangi Regency. This study uses a ticket sales system at the New Star Cineplex (NSC) Banyuwangi branch as the research object. Existing ticket sales are still using the manual system. Based on these problems, this type of exploratory qualitative research is suitable for investigating, solving, and providing solutions to the NSC cinema in Banyuwangi. The types of data used in this study are primary and secondary data. The primary data in this study were generated through in-depth interviews and observations with correspondents or employees at the NSC cinema and the audience and the management or managers of the NSC cinema in Banyuwangi Regency. This secondary data can be in the form of recorded interviews, photos of observations, and documents related to the existence and ticket sales system at the NSC Banyuwangi cinema. Secondary data sources are employees and management at the NSC Banyuwangi cinema.

The methods used to collect data in this study are as follows:

1) Observation. Data collection with the observation method means that the researcher observes the object of research, which is the ticket sales system carried out by the NSC cinema in Banyuwangi Regency.

2) Interview. This method is done by asking questions both orally and in writing and doing face-to-face. Interviews were conducted on parties who directly influence activities at the NSC cinema in Banyuwangi. Moreover, it will also be done to the audience who are consumers in this cinema business.

3) Documentation. Documentation is used as supporting evidence from the collection of observation and interview data. Documentation in the form of ticket sales data at the NSC 
Banyuwangi cinema, the results of written interviews, and recordings for interviews conducted orally. The source of this data is the results of interviews and observations of both managers, employees, and viewers at the NSC cinema in Banyuwangi.

The unit of analysis used in this study is the ticket sales system carried out by the NSC cinema in Banyuwangi Regency. All data that has been successfully collected will be analyzed using related journals and relevant books in terms of e-commerce, system development, and information systems.

The analysis in this study uses 3 (three) stages which are arranged starting from the existence of problems to the design of the e-commerce system offered related to ticket sales at the NSC Banyuwangi cinema. The following are the stages of the analysis technique: (1) Identifying the problem. The problem is that ticket sales are still made manually, while globalization has touched all levels of society. As a result of ticket sales that are still manual, NSC cinema revenue in Banyuwangi is still not optimal. (2) Perform analysis based on the problems that have been found. The analysis uses related journals and books that discuss e-commerce, system development, and information systems. Before carrying out the analysis, an evaluation of the system that has been running is carried out first. (3) Designing an applicable ticket sales system. The new system design will refer to the existing system's problem analysis and evaluation results, resulting in a better design.

\section{RESULTS AND DISCUSSION}

New star cineplex is one of the businesses in the entertainment sector. This business is relatively new in Banyuwangi Regency. New Star Cineplex was established in 2011 in Malang. Until now, the new star cineplex already has 7 branches in various districts, namely in Malang, Pasuruan, Jember, Madiun, Bojonegoro, Kudus and Banyuwangi. In Banyuwangi Regency, New Star Cineplex was only established in the middle of 2014. New Star Cineplex Cinema has a big opportunity in Banyuwangi Regency. This is based on the fact that NSC Cinema is the only cinema in Banyuwangi Regency.

This cinema is very helpful for the Banyuwangi community, especially in fulfilling their entertainment needs. On the other hand, this cinema also helps improve the economy in Banyuwangi Regency by contributing to the payment of entertainment taxes. The taxes received by the Banyuwangi Regency from businesses are pretty significant. The cinema business is quite successful because ticket sales continue to increase every month and considerable tax contributions. However, in 2016 ticket sales at NSC decreased, and the prevailing system caused this decrease.

The current system at the New Star Cineplex is conventional. Where buyers can only buy and make reservations by coming directly to the cinema, and purchases and reservations are made directly through the cashier. According to Linda in 2017, a New Star Cineplex employee, another way to make a reservation is by contacting one of the employees via telephone, BBM, WhatsApp. There is no official site to buy or book nsc cinema tickets online.

The limitations of the conventional system can cause several problems, such as a decreased number of sales, a decrease in audience loyalty due to a decrease in service quality, or a level of disappointment due to the unavailability of the desired ticket or seat. The following is the flow of ticket purchases at the New Star Cineplex cinema, sourced from the SOP document for the New Star Cineplex, Banyuwangi Regency. We can conclude that bookings or ticket purchases are made directly at the New Star Cineplex Cinema cashier. Prospective buyers come to the New Star Cineplex Cinema and then queue up to order tickets.

\subsection{Weaknesses of the Current System}

According to Dimas in 2017, one of the moviegoers of the New Star Cineplex, the system is considered ineffective, especially for himself as an employee. It is challenging to buy or order tickets, and there needs to be free time to order tickets. Not infrequently, when they have time to come to the New Star Cineplex Cinema, prospective audiences go home disappointed because the desired movie tickets are already out of date. Seliaan, prospective viewers must be willing to queue for a long time.

For orders made via employees, the difficulty faced by prospective buyers is the response from management or employees. Not all potential viewers have a relationship with New Star Cineplex Employees. In terms of sales quality, this conventional system has an impact on the decline in ticket sales. Furthermore, ticket sales and bookings are less than optimal.

\subsection{System Required}

Based on the results of the analysis of the ticket purchase system at the Banyuwangi branch of the NSC 
cinema and the system's weaknesses described previously. An overview or general outline of the system needed for the Banyuwangi branch of NSC cinema is a ticket purchase system that customers or spectators can access to make reservations or reservations. The system will cover the weakness of the ticket purchasing system currently available at the Banyuwangi branch of the NSC cinema. So, the system needed is simple but can show the information needed by the audience. The often needed information is the film's title being screened, the show schedule, a map showing the number of available seats, and the unfilled seat positions. The following are the system requirements in designing the ticket purchase system at the Banyuwangi branch of the NSC cinema.

\subsubsection{Hardware Requirements}

Alternatively, hardware needed in the new ticket purchase system is a set of computers, smartphones, and wifi hotspots or hardware that can be used for internet access in general. Overall, this hardware has been fulfilled both from the side of the Banyuwangi branch of the NSC cinema as a seller and from the customer or buyer side.

\subsubsection{Software Needs}

in the form of website services, can be accessed by all parties. In this case, the only difference is in the menu used. The Banyuwangi branch of NSC will have an admin menu in which the film schedule can be updated, the currently playing films, and the remaining unsold seat quotas. Updates made by the Banyuwangi branch of NSC cinema officers will result in an appearance on the website. The website opened by the customer will only provide a reservation menu, seat options that are still available, and payment. The payment menu has two options. First, the customer or buyer can upload proof of payment. Both buyers can exercise a "pay on the spot" option. The second option contains an announcement that subscribers who choose this option must have paid 10 minutes before the film is shown. This was done to avoid losses for the Banyuwangi branch of the NSC cinema. So, when a customer who chooses the second option does not pay within 10 minutes before the movie is shown, his reservation will automatically be canceled, allowing other customers who have not made a reservation to buy the canceled ticket. Because the software used is website-based, it can be concluded that the software needs are met and can be applied to any hardware connected to the internet network.

\subsubsection{Human Resources Needs}

Talking about the system must also be related to the users of the system, namely humans. The system must be able to operate according to its function. So that making the system also pays attention to the quality of Human Resources (HR) who will become users. In response to this, the system produced in this study is simple so that all users can access it. To access or operate this system does not require Human Resources (HR) with unique skills. Except for system development, the Ministry of Religion requires particular expertise, namely in the IT field, to structure the system in such a way. Analysis of human resource requirements to operate this system is also felt to have been fulfilled.

\subsubsection{Cost}

Requirements The cost requirement for both system development and implementation is considered not too significant. In other words, the benefits provided will be greater than the costs that may be incurred. Considering that the hardware is already available, the software is also free if you use the website. The need for human resources is more than sufficient because access to a website is the most basic search engine skill, and it can be said that anyone with hardware or a smartphone can do it.

\subsection{System Design}

In the context diagram, it is explained that three parties will be involved in the E-ticketing system. Of the three parties, there are two direct parties, namely the Orderer/User and Admin/Officer as the operational party, and there is one indirect party, namely the Head Office, which is represented by a manager who is in charge of the controller in cinema operational activities and the position in the ticket booking cycle. Done online at the NSC Banyuwangi branch can also be eliminated so that the context diagram does not show the role of a manager.

DFD level 0 is a detail of the activities that have been listed on the context diagram. The following explanation is a level 0 DFD of online cinema ticket booking. DFD level 0 illustrates that there are three activities or processes in ordering cinema tickets online. The three activities are registration, reservation, and recording of both information records and financial records relating to tickets that have been booked. So that the cinema (officer) can update the financial records of ticket sales and changes to the information displayed on E-ticketing. DFD level 1 is a breakdown of activities that have been listed on DFD 
level 0 . The following explanation is a level 1 DFD of ordering cinema tickets online.

Users to the reservation stage must pass the registration stage or create a customer account. At this stage, three activities must be carried out, namely (1) filling in the identity of the customer, (2) waiting for confirmation from the admin for registration and filling in the identity, and (3) when it is confirmed, the customer will get a Buyer ID which will be used later. To $\log$ in when going to make a reservation or order tickets.

The registration stage to the recording stage of ticket reservations must go through three activities: details of the reservation stage. These activities are (1) logging in using the Buyer ID, (2) selecting the movie, showtime, and studio used to watch, and (3) the customer will make a payment and get a Transaction ID which is used as proof that they have made a ticket reservation online.

The last stage is the recording of ticket reservations that the customer has made. This stage consists of three activities, namely (1) inputting the Transaction ID obtained by the customer, (2) from the input it will automatically reduce the inventory of seats sold to the next customer (information recording) and will affect or increase revenue receipts for transactions that have been made. Occurs, and (3) the admin will update the data for changes in the recording that have occurred.

Entity Relationship Diagram (ERD) is a model used to describe the relationship between databases used by an entity. Figure 1 presents the ERD that NSC Banyuwangi Branch should use.

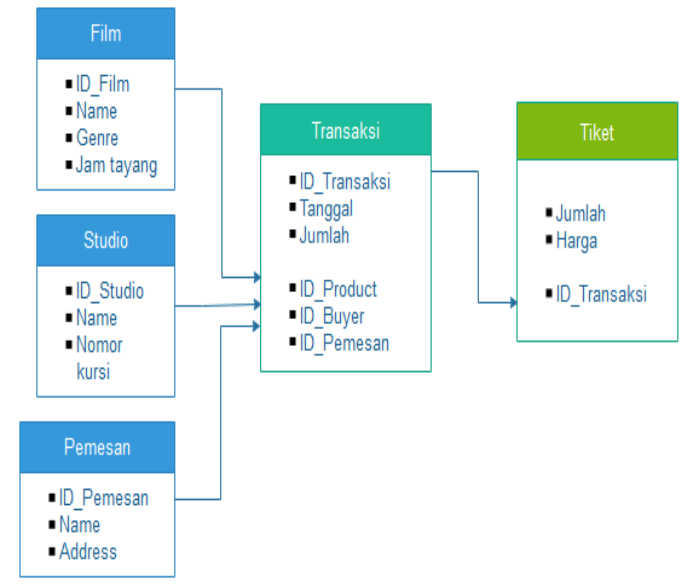

Figure 1. Proposed Entity Relationship Diagram (ERD) for NSC Banyuwangi Branch

Source: Processed results, 2017

\section{CONCLUSION}

There is a system design e-ticketing to increase ticket sales at the Banyuwangi branch of NSC. This is needed to fulfill the information needed by customers and cover the weaknesses that exist in the old ticket purchasing system. An online-based ticket purchase system should be implemented at the Banyuwangi branch of the NSC cinema. Recommendations for the design of the new ticket purchasing system can be followed up by developing the system.

\section{AUTHORS' CONTRIBUTIONS}

All authors contributed to successfully research conduct and write the manuscript for publications.

\section{ACKNOWLEDGMENTS}

We thank the management of Banyuwangi Cineplex for permitting us to research. We also thank Universitas Airlangga PSDKU Banyuwangi for supporting research and recommendation for publication.

\section{REFERENCES}

[1] Banyuwangi, Banyuwangi's Per Capita Income Soared Sharply (Online), [2015]. Available from http://www.banyuwangikab.go.id/beritaregion/pendapatan-per-capita-banyuwangimelonjak-tajam.html. Accessed March 15, 2017.

[2] N. Singh, et al, "Consumer acceptance of apparel e-commerce-Ethiopia," Intellectual Economics., 10: 55-62, 2016.

[3] K. Cao, and Z. Yang, "A study of e-commerce adoption by tourism websites in China," Journal of Destination Marketing \& Management., vol. 5, pp. 283-289, 2016.

[4] F. T. C. Tan, et al, "Developing business analytic capabilities for combinating e-commerce identity fraud: A study of Trustev's digital verification solution," Information \& Management., vol. 53, pp. 878-891, 2016.

[5] K. C. Laudon, and J. P. Laudon, Management Information System Managing the Digital Firm 14th Edition. England: Pearson Education Limited, 2016.

[6] Z. Radovilsky, Application Models for ECommerce. India : Cognella Academy Publishing, Chennai, 2015. 
[7] D. Priyanti, and S. Iriani, "Sistem Informasi Data Penduduk Pada Desa Bogoharjo Kecamatan Ngadirojo Kabupaten Pacitan," Indonesian Journal on Networking and Security., vol. 2, no. 4, pp. 55-61, 2013.

[8] M. B. Romney, and P. J. Steinbart, Accounting Information System. 12th Edition. England : Pearson Education Limited, 2012.

[9] American Heritage Dictionary, The American Heritage ${ }^{\circledR}$ Dictionary of the English Language 5th Edition, Houghton Mifflin Harcourt Publishing Company [Internet], 2013. Available from : http://www.yourdictionary.com/typology \#americanheritage. Accessed April 20, 2017.

[10] G. Gupta, S.K. Zaidi, G. Udo, and K. Bagchi, "The Influence of Theory of Planned Behavior, Technology Acceptance Model, and Information System Success Model on the Acceptance of Electronic Tax Filing System in an Emerging Economy, " The International Journal of Digital Accounting Research, vol. 15, pp. 155-185, 2015. 